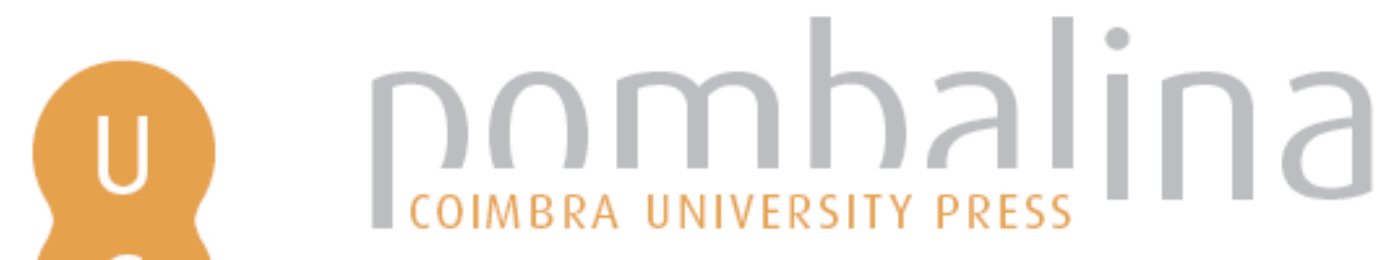

\title{
The function of dream-stories in Plutarch's Lives
}

Autor(es): Romero-González, Dámaris

Publicado por: Imprensa da Universidade de Coimbra

URL

persistente: URI:http://hdl.handle.net/10316.2/47488

DOI: $\quad$ DOl:https://doi.org/10.14195/978-989-26-1765-7_2

Accessed : $\quad$ 26-Apr-2023 14:55:45

A navegação consulta e descarregamento dos títulos inseridos nas Bibliotecas Digitais UC Digitalis, UC Pombalina e UC Impactum, pressupõem a aceitação plena e sem reservas dos Termos e Condições de Uso destas Bibliotecas Digitais, disponíveis em https://digitalis.uc.pt/pt-pt/termos.

Conforme exposto nos referidos Termos e Condições de Uso, o descarregamento de títulos de acesso restrito requer uma licença válida de autorização devendo o utilizador aceder ao(s) documento(s) a partir de um endereço de IP da instituição detentora da supramencionada licença.

Ao utilizador é apenas permitido o descarregamento para uso pessoal, pelo que o emprego do(s) título(s) descarregado(s) para outro fim, designadamente comercial, carece de autorização do respetivo autor ou editor da obra.

Na medida em que todas as obras da UC Digitalis se encontram protegidas pelo Código do Direito de Autor e Direitos Conexos e demais legislação aplicável, toda a cópia, parcial ou total, deste documento, nos casos em que é legalmente admitida, deverá conter ou fazer-se acompanhar por este aviso.

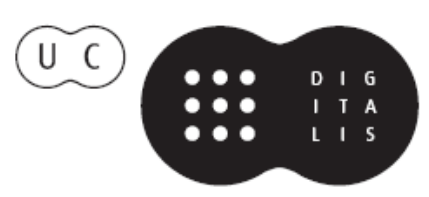




\section{Visitors from beyond the Grave}

\section{Ghosts in World Literature}

Dámaris Romero-González, Israel MuñozGallarte, Gabriel Laguna-Mariscal (eds.) 


\title{
The Function of Dream-Stories in Plutarch's Lives
}

\author{
DÁMARIS ROMERO-GONZÁLEZ \\ University of Córdoba \\ (orcid.org/0000-0001-6234-9687) \\ "oftentimes to win us to our harm, \\ The Instruments of darkness tells us truths, \\ Win us with honest trifles, to betray's \\ In deepest consequence" \\ (W. Shakespeare, Macbeth A1 S3 123-126)
}

\begin{abstract}
Aвstract: In his Lives Plutarch relates many dreams that can be considered as oracular or symbolic dreams. Some of them have a ghost as the main character, a ghost who comes from beyond to warn the dreamers about the closeness of their death. This chapter will analyse both the function of these dreams in three lives and how they are connected to the biography of the protagonist.

Keywords: Plutarch, dreams, ghosts, Cleonice - Pausanias, Caesar - Cinna, Gaius Tiberius Gracchus.
\end{abstract}

There is a considerable number of dreams narrated in Plutarch, especially in his Lives, probably because of his conception of them as prophetic. The dream is the moment when the soul "is relaxed and released from their present state as they range amid the irrational and imaginative realms of the future" (De defectu oraculorum $432 \mathrm{C})^{1}$. Another reason to introduce the dreams would be that gods could use them as a direct way to mingle with humans. It seems to be surprising the number of dreams in Plutarch through which a god speaks directly to the human to reprimand their intentions, to reassure them or to change their fate.

Most of the dreams are prophetic, and they are dreamt by main characters prior to an important event, such as the birth ${ }^{2}$ or the death ${ }^{3}$ of the protagonist,

${ }^{1}$ As Brenk 1987: 260 explains, it is possible to find two visions in Plutarch about dreaming: there is one related to the superstitious person, whose dreams are ridiculed, and a second one, collected in Amat. 764F, which describes the dream world as "that in which we are closest to a vision of the Forms, the true period of consciousness". It does not mean that he considers all dreams as truthful; he quotes, for instance, the dream of Lysander (Lys. 20. 5) about the end of the siege of Aphytis, ordered by Zeus Ammon, as an excuse for leaving Sparta after Pharnabazus' denunciations of Lysander's pillage of the Persian territory.

${ }^{2}$ Alex. 2. 3, 4-5; Per. 3. 2; Cic. 2. 1-2; Rom. 2. 6.

${ }^{3}$ Alc. 39. 2-3; Alex. 50. 6; Arist. 19. 2; Brut. 20. 5-6; Caes. 63. 9, 68. 3; Cim. 18. 2; Dem. 29. 2; Mar. 45. 6; Sull. 37. 4. 
or a crucial battle ${ }^{4}$, whose result is predicted in the dream. Gods ${ }^{5}$, heroes ${ }^{6}$ or animals ${ }^{7}$ usually star in these dreams, and all of them interact with the dreamer. As well as these characters, it is also possible to find ghosts of the recently deceased ${ }^{8}$.

However, despite the large number of dreams in Plutarch, they have been usually studied alongside the dreams narrated by other authors', as examples of the type of dreams (symbolic dream, hórama or vision, and khrematismós or oracle); the role played by the dreamer (active or passive); the origin of the dream (from within or beyond the dreamer) or the attitude of the philosophers towards them ${ }^{10}$. It was not until the studies of F.E. Brenk about the use of dreams in the Lives that this type of narration received attention solely in Plutarch ${ }^{11}$. He paid special attention to the Plutarchean concern for inserting dreams in the narration, that is, to the significance or purpose of the dream (prophetic, biographical or motivating dream) and, especially, to the psychological moment it takes place (anxiety or crisis), as well as the type of dream and its techniques (visual symbolism or/and spoken parts).

Following the purposes stated by Brenk, our aim is to develop how Plutarch either illuminates the character of the hero or offers reason for the following action(s) of the protagonist. Therefore, we will analyse, on the one hand, the dreams, taking into account the immediate and broader context of the passages and the dreams themselves, and we will expose how Plutarch connects them to achieve his objective; on the other hand, we will observe the links between the dreams and the literary tradition, especially those related to the traged $y^{12}$. To this end, the dreams of the strategos Pausanias, the poet Cinna and the tribune Gaius Gracchus will be considered.

So, in the first place, we will analyse the literary form of these dreams; secondly, we will explain the biographical or motivating functions of these

${ }^{4}$ Ages. 6. 5; Alex. 18. 6-8, 24. 5; Arist. 11. 5; Caes. 32. 9, 42. 1; Demetr. 29. 2; Eum. 6. 8; Pel. 21. 1; Pomp. 32. 8, 68. 3; Pyrrh. 11. 3, 29. 2-4; Sull. 9. 6; Timol. 8. 1.

${ }^{5}$ Arist. 11. 5-6 (Zeus); Lys. 20. 5 (Zeus Ammon); Cor. 24.2 (Iuppiter); Luc. 10. 3 (Athena and Persephone), Per. 13. 8 (Athena); Luc. 12. 1 (Aphrodite); Them. 30. 1 (Mother of Gods); Rom. 2. 5 (Cybele); Tim. 8. 1 (Demeter and Persephone); Sull. 9. 4 (Bellona).

${ }^{6}$ Alex. 24.5 (Heracles); Luc. 23.3 (Autolycus).

${ }^{7}$ Cim. 18. 2-3 (bitch); Them. 26. 2-3 (snail + eagle). It is even possible to find natural phenomena as protagonists of the dreams: Alex. 3. 3; Ant. 16. 4; Pyrrh. 29. 1.

${ }^{8}$ Brut. 20. 5-6; Caes. 68. 3; Pomp 73. 3; CG 1. 7; Sull. 37. 4.

${ }^{9}$ There are studies dedicated to the presence of the dreams in the tragedy, as the classic one of Devereux 1976; or in the novel, Macalister 2013.

${ }^{10}$ Probably influenced by Dodds 1997: 103-131. One of the most recent studies about the dream in general is Harris 2009.

${ }^{11}$ Brenk 1975: 336-349 (= 1998: 336-349); Brenk 1977: 214-235.

${ }^{12}$ Brenk 1998: 344. The scheme of the literary form is taken from Hanson 1989: 1405-1414 with variations. 
dreams and pay attention to some elements of these dreams, and, finally, we will offer some final conclusions.

\section{Literary form of the dreams of Pausanias, Cinna and Gaius GraCCHUS}

The dreams mentioned above share a literary form, which "does not significantly change from the Homeric poets to the end of late antiquity" ${ }^{13}$. This literary form is divided into three sections, related to the moments of the narration: first, the beginning or scene-setting, in which the dream is contextualized; second, the development of the dream or the dream-vision proper, and, third, the conclusion of the dream-story ${ }^{14}$.

\section{Scene-setting}

Within this section, Plutarch contextualizes the dream: He identifies the dreamer, the place where the dream takes place and the time when it is set. Moreover, he adds information in relation to the ghost (dream figure), especially the identification of the ghost (it could be considered as its description) and the relationship it has with the dreamer ${ }^{15}$.

First, the dreamer is identified by name, as it happens in the case of Cinna and Pausanias; however, this is not the case with Gaius, as this identification is not necessary considering that he is the protagonist of the Life. Relating to the ghosts, Plutarch does not describe them. It seems that they would look alike as when they were alive, because they are recognized by the dreamers ${ }^{16}$. Next, both the dreamer and the ghost are also identified by their relationship ${ }^{17}$. Thus, Cinna is a friend of Caesar (Caes. 68. 3; Brut. 21. 8) in the same way as Gaius is the brother of Tiberius (CG 1.6), whereas Pausanias is the killer of Cleonice (Cim. 6. 4).

${ }^{13}$ Hanson 1980: 1396.

${ }^{14}$ The dream-story and the ghost story share a quite similar literary form (both have the scene-setting, the development of the scene and the conclusion) and one of the functions of their main character -dream figure or ghost- is to predict the future to others. Due to these similarities, we will make use of the terminology associated to the ghosts stories whenever necessary.

${ }^{15}$ Hanson 1980: 1410 inserts this information later, in the "dream-vision proper" group. For this section, I will borrow the structure developed by Hanson but with variations.

${ }^{16}$ In Plutarch the appearance of humans (dead or alive) is usually alike in the world of livings, so Alc. 39. 1-2; Alex. 18. 6-7, 50. 6; Arist. 19. 2; Demetr. 4. 2, 29. 1-2, 29. 1; Demetr 29. 2; Eum. 6. 6; Pyrrh. 11. 2; Caes. 32. 9, 63. 9-10; Pomp. 32. 3, 68. 2, 73. 3; Sull. 28. 4, 37. 2. For the different "physical" appearances of ghosts, see Winkler 1980: 159; Felton 1999: 17-18; Stramaglia 1999: 36-41 and Ogden 2001: 221-225 (in a necromantic context).

${ }^{17}$ These ghosts remember their past life and their relation with the living. They can also impart information about the future of the dreamer, cf. Ogden 2001: 242, Muñoz 2010: 309. 
Second, the time when the dream occurs is at night. While in the case of the dreams of Pausanias and Cinna is said explicitly that the dream occurs at night (nuktôr, Cim. 6. 5; nuktos, Caes. 68. 3), in the dream of Gaius any indication is given. Nonetheless, it is more interesting the psychological time when the dream takes place: it corresponds to a moment of emotional or physical crisis for the dreamer, who is normally surrounded by anxiety. Thus, Pausanias is sure that his ending as strategos is soon after his betrayal of the allies to the Persians (Cim. 6. 3), Gaius has retired of the public life due to his brother's recent death (CG 1.1) and Cinna is suffering from high temperature (Caes. 68. 4; Brut. 20. 10). It is noteworthy that this anxious time serves as intensifier of the fateful prediction given by the ghost to the dreamer, that is, the close death in the three dreams. Because of this, and not without reason, it was thought that the contact with the ghost, no matter what it was, would bring a sure death to whom the ghost has appeared ${ }^{18}$.

Third, the place where the dream occurs is usually said in the dreams. However, Plutarch only gives the place in the Pausanias' dream (Byzantium), while in the other two it could be deduced from the close context (Rome in both dreams).

Finally, another possible manner to mark the scene as a dream is through the dream-vision terminology, the idiomatic expressions for the origin of the dream and its introduction, and the term(s) for the dream or vision.

Plutarch insists on the origin of the stories from the tradition or other authors in order to make his reader be sure the dream is true, though he only specifies the name of one of them (Cicero). For that purpose, the Chaeronean introduces idiomatic expressions or sentences as $\dot{\omega} \varsigma \lambda \dot{\varepsilon} \gamma \varepsilon \tau \alpha$ (Cim. 6. 5), $\ddot{\omega} \varsigma$

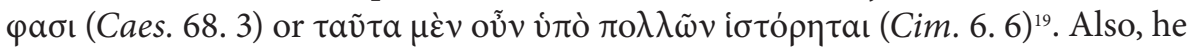
usually makes use of the idiomatic expression edokei to mark the beginning of the narration of the dream and to indicate that a dream is narrated ${ }^{20}$.

In relation to the terminology for referring to the dream, vision or ghost, Plutarch uses eidolon and opsis to make their presence note: he calls Cleonice eidolon, and opsis both Tiberius and Caesar. Though both words can be used synonymously ${ }^{21}$, eidolon seems to point to the ghost itself and opsis to the content of the dream (as a predictive content) ${ }^{22}$.

${ }^{18}$ Cf. Ogden 2002a: 157.

${ }^{19}$ For Pausanias' dream, his source may be Nymphis of Heraclea, because of the location of the consultation (Heraclea instead of Phigalia, cf. Paus. 3. 19. 7), cf. Ogden 2002b: 117. For Cinna's dream, his source could be Pollio, cf. Zadorojnyi 1997: 500-502. For Gaius' dream, the source is explicitly mentioned: Cicero, who collected it from Coelius Antipater (fr. 49), as the same as Valerius Maximus 1. 7 did.

${ }^{20} \mathrm{Cf}$. Hanson 1980: 1409. Though this idiomatic expression only appears in one of the three dreams analysed here (Caes. 68. 3), the presence in other Lives can be verified. For instance, in the Life of Alexander, the life that contains more dreams (8), it occurs seven times.

${ }^{21}$ Cf. Stramaglia 1999: 29.

${ }^{22}$ Eidolon, cf. Stramaglia 1999: 36-37; opsis, cf. Durán Mañas 2010: 240-244. 


\section{The dream-vision proper}

This section is referred to the message itself and the way it is said, if it is indicated by words (auditory dream-vision), by visual means (visual dreamvision) or both at the same time -although one or the other may dominate (audio-visual dream-vision). In the three dreams we have chosen, we only find the audio-visual and visual dream-visions ${ }^{23}$.

The language employed in both cases is enigmatic or at least fairly enigmatic, which means that the message would require some interpretation ${ }^{24}$, as in the case of Cleonice's ghost, who recited insistently to Pausanias some verses about the punishment and the end of the evildoers (Cim. 6. 4: "Draw you nigh to your doom; 'tis evil for men to be wanton"). Not all the messages are so obscure, as the dream of Gaius suggests: Tiberius, more clearly than Cleonice, predicts his brother's end (CG 1. 6: "Why, pray, do you hesitate, Gaius? There is no escape; one life is fated for us both, and one death as champions of the people").

Yet there is another language, also enigmatic, recited by the ghost through symbolic actions as Caesar does when he drags Cinna by the hand to a dark place to dine with him ${ }^{25}$.

\section{The conclusion of the dream-vision}

We could suppose that the narration of the dream would conclude with the fulfilment of the prediction told in it, and indeed that happens frequently ${ }^{26}$. Both Pausanias and Cinna died shortly after the predicted message (Cim. 6. 6; Caes. 68. 7-Brut. 20.6). However, there are dreams for whose fulfilment we must wait ${ }^{27}$, like Gaius' dream: his political career is described through all the life (chapters 2-16) and his death is narrated in chapter 17.

${ }^{23}$ As Hanson explains, 1980: 1411, “(i)n the seemingly contradictory expression 'auditory dream-vision', a dream-vision occurs in which something is heard only, usually the identified voice of the dream figure", as in Ages. 6. 5, Cleom. 7. 2. I would add the instances when this voice is represented by the pronoun tis, as in Luc. 23. 4 and Mar. 45. 3-4.

${ }^{24}$ In some dreams their interpretation is given shortly after, as for instance Alex. 2. 4-5, 24. 8; Cor. 24.3 or Luc. 10. 2.

${ }^{25}$ Cf. Brenk 1998: 339-341. In other occasions, it could be a mixture of both. This complexity could be increased and it is possible to find symbolic dreams with oracular characters, although they do not speak: Cic. 44 (Jupiter), Pomp. 73 (pilot), Sull. 9 (Selene), cf. Brenk 1977: 216-217.

${ }^{26}$ Some of them are, for instance, Alc. 3. 1-2; Alex. 18. 6-7, 24. 4-8; Arist. 11. 5-6; Cim. 18. 2-3; Dem. 29. 1; Eum. 6. 6; Pyrrh. 11. 2; Them. 30. 1-2; Caes. 63. 9-10; Luc. 10. 2-3, 12. 1-2. All these dreams have their fulfilment either immediately or a few lines further on.

${ }^{27}$ We will find, obviously, the same wait in the dreams that predict great and important deeds before someone's birth (cf. Alex. 2. 3-5; Per. 3. 2; Cic. 2. 1-2; Rom. 2. 6). 


\section{THE FUNCTION OF THE DREAMS}

As Hanson writes ${ }^{28}$, "the dream-visions are not merely decorative, but often function to direct or redirect the movement of the narrative"; Plutarch, being conscious of the possibilities of the dream, inserts the dream with a main function: to predict the fate of the dreamer, and this function is without variation in the three dreams. But, at the same time, he uses the dream either to illuminate the character of the hero or to offer motivation or reason for the following action(s) of the protagonist or some characters.

\section{The dream of Pausanias: biographical function}

The dream that exemplifies the biographical function is Pausanias'. Plutarch turns to this story not only as a means to dramatically predict the death of the character, but also as a portrait of Pausanias. This story has two parallel texts in Moralia 555C and in Pausanias 3. 17, to that we will turn to complete the portrait that Plutarch gives of Pausanias in the Life.

Some lines before the dream, Plutarch has drawn the personality of Pausanias: he has betrayed his comrades in arms after having formed a secret alliance with the Persian for his own benefit (Cim. 6. 2) ${ }^{29}$; his way of treating the allies was tyrannical and offensive due to his rudeness of giving orders, and, as the epitome of his portrayal, his lack of control of his desires, exemplified by the story of Cleonice.

Cleonice was a young Byzantine girl demanded by Pausanias to be dishonoured. Unfortunately, on her way to bed (the lights of the room were put out by her request), the Spartan general, believing she was an enemy, murdered her by mistake. After her death, as a result of the wound, she gave Pausanias no peace. She kept coming into his sleep by night as a phantom, wrathfully uttering these verses referred to the retribution for the excess:

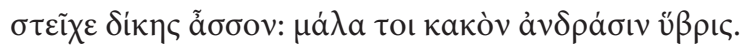

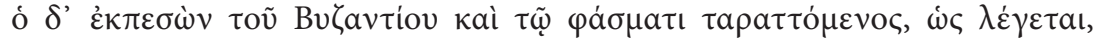

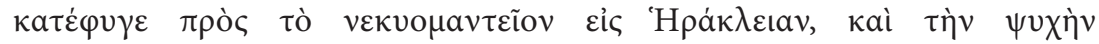

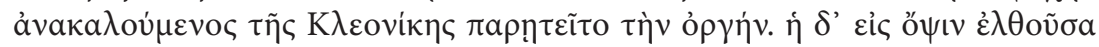

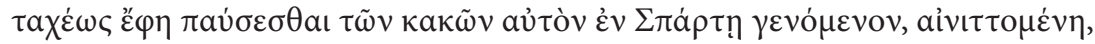

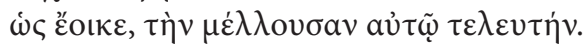

${ }^{28}$ Cf. Hanson 1980: 1413.

${ }^{29}$ Cf. Hdt 5. 32, Th. 1. 95, 128-131, where his huge ambition for exercising control over all Greece is present. Gómez Espelosín 2013: 187 adds that this pro-Persian tendency was sought for Pausanias himself because he wanted to be part of the Persian politics. 
"Draw thou nigh to thy doom; 'tis evil for men to be wanton."

(...) Driven from Byzantium, and still harassed by the phantom, as the story goes, he had recourse to the ghost-oracle of Heracleia, and summoning up the spirit of Cleonice, besought her to forgo her wrath. She came into his presence and said that he would soon cease from his troubles on coming to Sparta, thus darkly intimating, as it seems, his impending death (Cim. 6. 5-6).

We notice that Plutarch insists on the negative portrait of Pausanias with this episode ${ }^{30}$, turning firstly to the virtue of Cleonice: she asks the guards to take away the lights of the bedroom before she enters, which contrasts with the depravation of Pausanias ${ }^{31}$ : Plutarch explicitly highlights that he wants to

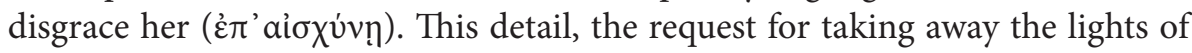
the bedroom, is not present in the parallel text of Pausanias (3. 17. 8), in which the candle of the room is alight, so it would reinforce the idea that Plutarch is using the narration of a dream with both a biographical and moral purposes.

Moreover, the fear of the parents of Cleonice ${ }^{32}$ emphasizes the tyrannical behaviour of Pausanias ${ }^{33}$, mentioned before in relation to his behaviour with the allies (hubrizontos, 6. 2). This fear provokes the abandonment of the daughter to her fate when she was required in Pausanias' presence. Likewise, this behaviour is also highlighted in Moralia 555C, where Plutarch writes that the Spartan made her require his presence with arrogance (hubrei). Thus, the lust and the tyranny of Pausanias make him continue with the Herodotean portrait of a tyrant ${ }^{34}$.

There are two aspects in this story related to Cleonice and the plot that it would be worthwhile to point out. It is not a coincidence that Cleonice is a biaiothanatos, the ghost of a person who has died violently, as they were the ideal to perform a necromantic ritual ${ }^{35}$. These ghosts remember their past lives and their relation with the living, and they can impart information about the future of the dreamer ${ }^{36}$. Thus, Cleonice is able to predict the death of Pausanias in such enigmatic way: "he would soon cease from his troubles on coming to Sparta" (Cim. 6. 8).

${ }^{30}$ Also, the episode marks the different fates of the protagonists, Pausanias and Cimon. After the murder of Cleonice, the fall of Pausanias begins, as the allies could not bear his tyrannical behaviour and join Cimon to throw out Pausanias from the city, while the rise of Cimon starts out by leading the allies to Thrace as strategos (Cim. 7. 1), cf. Amendola 2007: 239-240.

${ }^{31}$ Cf. Amendola 2007: 239.

${ }^{32}$ Neither in the parallel text of Pausanias or in Moralia do the parents of Cleonice appear.

${ }^{33}$ This tyrannical behaviour could be read in Arist. 23. 2-3; D.S. 11. 46. 4-5; Th. 1. 95, 130; Nepos Ar. 2. 3.

${ }^{34}$ Cf. Stadter 1995: 227.

${ }^{35}$ Cf. Ogden 2001: 226.

${ }^{36}$ Cf. Ogden 2001: 242, Muñoz 2010: 309. The ghosts of Caesar and Tiberius are also biaiothanatoi. 
In relation to the plot, the story of Pausanias and Cleonice seems to be a synthesis of different traditions. The main story has parallel themes in the episode of Periander and Melissa narrated by Herodotus (5.92): the sentimental attachment without measure to a girl, the murder of her and the necromantic invocation of her ghost. Periander was the tyrant of Corinth who desired intensively his wife, Melissa (he committed necrophilia with her dead corpse) and also killed her by accident (he killed her after the slanders about her of her maidservants $)^{37}$. Shortly after, he went to a nekuomanteion to placate her and called up the ghost of Melissa to ask what he wanted to know $^{38}$.

At the same time, the Plutarchean story collects the oldest tradition of the ghost who returns to haunt who has wronged him or her. The first ghost who returns from Hades to haunt someone appears in tragedy, in the Aeschylian The Eumenides: the ghost of Clytemnestra harasses Orestes because he killed her, and she harasses him through the Erinyes ${ }^{39}$, and, just as Cleonice, with wrath.

\section{The dreams of Cinna and Gaius Gracchus: motivational function}

Besides the biographical function, another reason to insert a dream in the narration is the motivational: the dream is used to explain the actions of a character. The dreams of Cinna and Gaius Gracchus are clear examples of it.

Let us start with the apparition of Caesar to $\mathrm{Cinna}^{40}$, his poet friend, in his dream. Caesar has died recently, and the streets of Rome are burnt as people have been profoundly moved after the reading of Caesar's will. Due to this fact, they, burning with fury, cried out to kill Caesar's murderers. In such an environment, Cinna dreamt that

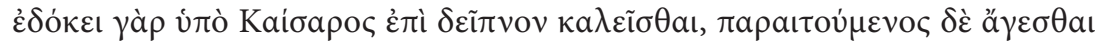

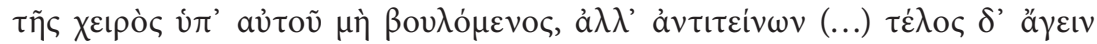

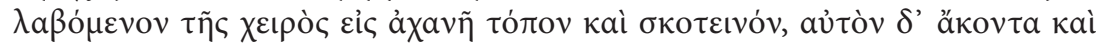

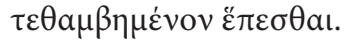

he was invited to supper by Caesar, and that when he excused himself, Caesar led him along by the hand, although he did not wish to go, but resisted (...)

${ }^{37}$ The accidental death of Melissa is told by D.L. 1. 94 and Paus. 2. 28. 8; Herodotus only gathers that he killed Melissa (Hdt. 3. 50. 1)

${ }^{38}$ The main difference between the ghost of Melissa and the ghost of Cleonice is the reason why they haunted their male partners: Melissa, in contrast to Cleonice, does not hunt Periander because he killed her but because of an improper burial. For a comparison between the three parallel texts, cf. Ogden 2002b.

${ }^{39} \mathrm{cf}$. Devereux 1976: 155.

${ }^{40}$ Cf. Plu., Caes. 68. 3; Brut. 20. 5-6; cf. V.Max. 9. 9. 1; Suet., Iul. 85; App., BC 2. 20. 147; D.C. 44. 50; Zonar. 10. 1. The sources identify him with C. Helvius Cinna, poet and friend of Catullus, but also with the tribune of 44 BC, cf. Zadorojnyi 1997: 500-502. For a biography of Cinna and his poetic context, cf. Wiseman 1974: 44-58. 
and finally took him by the hand and led him into a yawning and darksome place, whither he followed unwilling and bewildered (Caes. 68. 3; Brut. 20. 5-6).

This dream is only narrated in the Lives of Caesar and Brutus ${ }^{41}$-no other source does (though they add gorier details, like the head of Cinna stuck in a spear [Valerius Maximus and Suetonius] or his body torn in so many pieces that it was impossible to find them and bury the body [Appian]). But, once more, it would be due to the type of history Plutarch writes. In this occasion, he adds the dream as a motivation for the escape of Caesar's murderers ${ }^{42}$.

Besides detailing the death of Cinna, Plutarch inserts this dream when the tension in Rome is critical after the murder of Caesar. So, on the one hand, the mistaken death of Cinna is used to dramatically exemplify the moment. Once Caesar's will has been read -he bequeathed his properties and money to the people- and his robe (broken by the daggers and stained by his own blood) has been shown, the furious crowd is anxious for avenging Caesar no matter what it takes (Caes. 68. 7; Brut. 20. 6), even if it means killing the murderers ${ }^{43}$. On the other hand, it serves Plutarch to explain the rushed decision of Brutus and Cassius to leave the city immediately (the motivating function ${ }^{44}$ ) and wait for coming back to Rome until the fury has calmed down (Caes. 68. 7; Brut. 21. 1).

As we said, Plutarch inserts the dream for two functions: the obvious premonitory function and the motivating function, as seen previously. The premonitory function of the dream is emphasised by the eschatological language

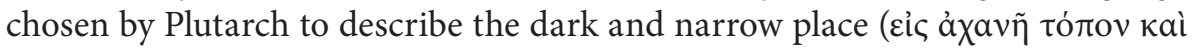

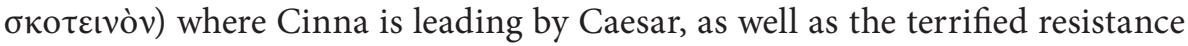
of Cinna ${ }^{45}$. Furthermore, the invitation for dinner symbolises a warning from Caesar to Cinna about the similar fate they share. Likewise Caesar in respect to Calpurnia's premonitory dream, the poet does not take it into account and goes to Caesar's funeral despite being feverish. Consequently, he finds his death,

${ }^{41}$ According to Brenk 1977: 222, the story of the dream might come from L. Crassicius of Tarentum, who published a commentary on Cinna's Zmyrna.

${ }^{42}$ Cf. Brenk 1977: 346.

${ }^{43}$ Shakespeare exemplifies in a masterful way the blind rage of the mob, when he makes Cinna introduce himself to them firstly with his name and later with his profession. They could not care less about his answers, as they wanted to kill him just because of his name (Julius Caesar A3 S3 vv. 26-34): “Third Citizen: Your name, sir, truly. / Cinna the Poet: Truly, my name is Cinna. / First Citizen: Tear him to pieces; he's a conspirator. / Cinna the Poet: I am Cinna the poet, I am Cinna the poet. / Fourth Citizen: Tear him for his bad verses, tear him for his bad verses. / Cinna the Poet: I am not Cinna the conspirator. / Fourth Citizen: It is no matter, his name's Cinna; pluck but his / name out of his heart, and turn him going".

${ }^{44}$ Cf. Brenk 1998: 346.

${ }^{45}$ Cf. Brenk 1977: 222. 
because the funeral attendees mistook his name for one of the assassins of Caesar, Cornelius Cinna, and they tore Cinna in pieces.

Though the dream is focused on Cinna, it passes the premonitory advice to the killers of Caesar, as is read in the following chapters of both Lives of Caesar and Brutus ${ }^{46}$. However, it might be worthy to go a step further and wonder whether the dream might also be considered as a reversed mirror of Caesar's death. Caesar, thus, would not only show Cinna his fate ${ }^{47}$ and the fate of his assassins but also the way they would die: The same manner as Caesar was bidding to go to the Senate and was led to his death by them, Caesar would lead his assassins to their deaths. Before the decisive battle in Philippi, Brutus is said to have seen in Philippi the good daimon that accompanied Caesar during his life (Caes. 69. 2, 6-13 $)^{48}$, and if we take into account the note of Valerius Maximus 1. 8. 8, Cassius also saw the ghost of Caesar before the same battle ("majestic beyond human aspect, robed in a purple commander's cloak, charging at him with threatening countenance"). Furthermore, same gestures and same deadly instruments were present in their deaths. Cassius killed himself with the same dagger he had used to murder Caesar (Caes. 69. $3^{49}$ ) and repeated the same gesture that Caesar had done on the Ides: he drew his cloak over his head (Caes. 66. 12, Brut. 17. 6). In turn, Brutus forced his breast against his naked blade (Caes. 69. 14), as the same manner he brandished his naked blade against Caesar on the Ides (Caes. 66. 10) ${ }^{50}$.

Finally, the last dream we will analyse is narrated in Gaius Gracchus 1. 6 and their protagonists are Tiberius and Gaius Gracchus. After the violent death of Tiberius (TG 19.6), Gaius abandons public life, although he does not become an idle, but dedicates himself to oratory and the military. Previously to his departure to Sardinia, his brother appears to him in his dream and addresses him, saying:

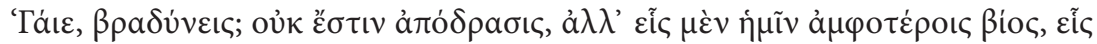

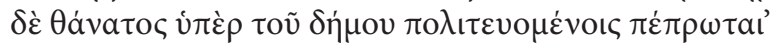

'Why, pray, dost thou hesitate, Gaius? There is no escape; one life is fated for us both, and one death as champions of the people' (CG 1.6)

${ }^{46}$ Cf. Pelling 1997: 228.

${ }^{47}$ Pelling 2010: 326 goes beyond the similar fate of Caesar and Cinna and notices the similarity of both deaths even in the gestures: the gesture of taking Cinna by the hand is the same as Decius Brutus when he took Caesar by the hand to the Senate the day when he was murdered.

${ }^{48}$ About this daimon, cf. Brenk 1977: 49-64 and 84-112.

${ }^{49}$ Suetonius adds the same detail in Iul. 89.

${ }^{50}$ Cf. Pelling 2011: 481, 500. 
The primordial purpose of the ghostly manifestation is similar to the others mentioned above: to disclose the eminent death of Gaius and to accept that his fate is linked to politics, similarly to what happened to Tiberius ${ }^{51}$.

By asking why Gaius is delayed, the ghost encourages him to return to public life. This delay might be due to the violent ending of Tiberius, not only in the politics, but also in his death, and so Gaius holds up his cursus honorum in order to avoid the same fate.

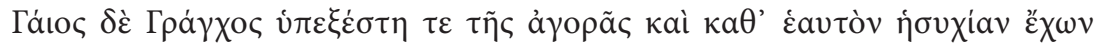

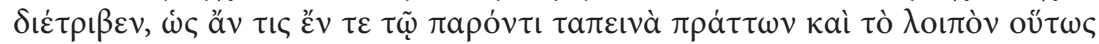

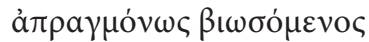

Gaius Gracchus (...) withdrew from the forum and lived quietly by himself, like one who was humbled for the present and for the future intended to live

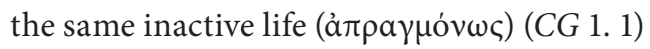

However, his decision is ruined and "he was led by a certain necessity rather than by his own choice to engage in public matters" (CG 1. 5). It is in this precise moment when Plutarch introduces the dream of Gaius with the apparition of Tiberius, in order to add the reason or necessity that obliges Gaius to change his decision. Thus, firstly, Plutarch justifies the change of mood of Gaius with the dream and his return to politics as tribune, which can be seen in CG 3. 1.

Second, the dream predicts the same political career of Gaius as Tiberius developed: to defend the interest of the people. While Tiberius has given back part of the ager publicus to the people, Gaius will add new members to the Senate from the equestrian order (TG 8. 7, CG 5. 2, Comp. Ag., Cleom. et Gracch. 2. 1). Moreover, it predicts the same way to die as Tiberius: to be murdered. Whereas Tiberius died as a result of being beaten by Publius Satureius and Lucius Rufus, Gaius will be murdered by his slave Philocrates (Gaius ordered his slave to do it), and both will be thrown to the Tiber (TG 20.2, CG 17. 5) ${ }^{52}$.

Even so, the dream is also motivational, as it explains what Gaius will do next: "to avenge his brother, who had been slain without justice or senatorial decree and without the concurrence even of a magistrate" (Comp. Ag., Cleom. et Gracch. 5. 5) ${ }^{53}$. In the last chapter of TG Plutarch has described an ill-willing city looking for the proper time for avenging the death. A similar picture is presented in the first chapter of $C G$, as Gaius feels an increasing fury for the murders of his brother during his momentary retirement. After the dream and

\footnotetext{
${ }^{51}$ Cf. Pelling 1986: 169-170; Pelling 2010: 35, for seeing the parallel between both lives.

${ }^{52}$ Cf. Vell.Pat. 2. 6.

${ }^{53}$ Cicero himself, although he is known for disagreeing with the Gracchi, justifies the vengeance of Gaius because of pietas fraterna (Cic. Rab.Perd. 14-15).
} 
his election as tribune, Gaius begins to attack his enemies, with his discourses remembering the unfair death of Tiberius and his friends, and with two laws that take aim at Octavius and Popilius ${ }^{54}$. His desire of vengeance was so intense that his mother herself intercedes on the repeal of the law against Octavius and asks him to abandon his vengeance, realizing the fatal consequences of it to the Roman Republic (Nepos, Fr. 1) $)^{55}$.

Taking into account this vindictive desire, it seems that Gaius would be playing the role of the Erinyes and, in some way, Tiberius Clitemnestra's. Like the Erinyes, Gaius is ready to avenge his brother after the dream, harassing the killers of his brother, while Tiberius performs Clitemnestra. He has been killed violently -thus both are biaiothánatoi, while his death was still without revenge and he encouraged his brother to act in a dream. Both Clitemnestra and Tiberius complain about the delay of the Erinyes and Gaius respectively ("will you not arise at one?" (Eu. 124) / "why do you delay?" (CG 1.6)), and they both expose plainly that there is no possibility to avoid their fate ("What task has been fated ( $\pi \dot{\varepsilon} \pi \rho \omega \tau \alpha$ ) for you except causing ill" (Eu. 125) / "there is no escape, but one life is fated ( $\pi \dot{\varepsilon} \pi \rho \omega \tau \alpha$ ) for us both, and one death as champions of the people" (CG 1. 6)). The only difference between Clitemnestra and Tiberius is the initial aim of their apparition: Clitemnestra seeks revenge while Tiberius does not: he only tries to obtain the fulfilment of his brother's destiny.

\section{Conclusions}

Through the literary framework, we have briefly exposed the sections that define a dream: the scene-setting, the dream-vision proper and the conclusion of the dream-vision. The latter section introduces the reason why Plutarch inserts dreams in his Lives: it is to foretell the death of the dreamer, but also to make the portrayal of a character or to give reasons for a character's behaviours in a certain manner.

However, Plutarch has not inserted the dreams without careful thought, and with great skill he interweaves the dream within the context in order to fulfil his aims. Thus, the last action of Pausanias -the murder of Cleonice- is the last stroke of a portrait described previously. Nevertheless, he goes beyond this and

${ }^{54}$ Thus Mommsen 2003: 126, and Roldán Hervás 2005: 178, although he refers to it in a soft way: "un primer paquete de medidas, inspiradas en el trágico fin de su hermano". Contra cf. Stockton 1979: 116-117. Once his revenge has finished, he begins to undertake his agrarian, military, federal, frumentary and judicial laws favourable to the people (CG 5), cf. Ward Heichelheim \& Yeo 2016: 161.

${ }^{55}$ According to López López 1991: 171, Cornelia does not disagree with the vengeance of Gaius, but she is trying to make him think about the consequences for him and for the Republic. Cornelia will become a less successful Volumnia, as she tries to warn him but fails in the attempt, cf. Nixon 2007: 27. 
re-enacts the previous context in the dream and in the following context. The dream of Gaius summarizes the life and the death of his brother and presages his own life and death. Moreover, the death of Caesar is repeated inside out in the dream of Cinna and in the deaths of Brutus and Cassius.

So, Plutarch makes us notice that the dream is not a mere anecdote in his works but it is at his service to enrich the moral purpose of his works. Even more, he makes us realize that the elements present in the dream are not accidental, but they are related to the dream figure and the dreamer within their stories. 